\title{
Conferência de Medellín e a paz como denúncia profética das injustiças no continente latino- americano
}

\author{
Medellin conference and the peace as a prophetic \\ denunciation of injustices in Latin American continent
}

Pedro Luiz Amorim Pereira

\section{Resumo}

Os acontecimentos que cercaram a Segunda Conferência do Episcopado Latino-Americano em Medellín, revelam muito sobre a redação do próprio documento. Em um continente cujas principais nações eram governadas por regimes autoritários que maquiavam as grandes desigualdades sociais, os bispos reunidos em Medellín, mostraram por meio de um impactante texto, o quanto estavam inseridos na realidade dos empobrecidos. O presente artigo traz um comparativo entre o capítulo da Paz no texto de Medellín e as realidades presentes em três grandes países do continente (Brasil, Argentina e Paraguai). A política autoritária e a grande discrepância social são denunciadas no texto que tomou por base a encíclica Populorum Progressio de Paulo VI e o movimento transformador proveniente do Concílio Vaticano II. Dados políticos e econômicos alheios ao ambiente da teologia colaboram na percepção da capacidade de análise de conjunturas relacionadas às situações nas quais a própria Igreja Católica estava inserida.

Palavras-chave: Medellín. Paz. Justiça. Ditadura Militar.

\section{Abstract}

The events that surrounds the Second Latin American Episcopate Conference in Medellín reveals much about the document itself. In one continent, which the main countries were ruled by authoritarian regimes who caused great social inequalities, the bishops gathered in Medellin used an impactful text, to show the reality of the simplest peoples. This article try to make a comparison between the chapter of peace in 
Medellin's text and how it is related in three major countries of the continent (Brazil, Argentina and Paraguay). An authoritarian policy and a large social discrepancy are denounced in the text based on Paul VI's Populorum Progressio and the transformative movement proved by the Second Vatican Council. Political and economic data unrelated to theology helps in perception of the bishops ability to analyze related conjunctures as situations in which the Catholic Church itself was inserted.

Keywords: Medellín. Peace. Justice. Militar Dictatorship.

\section{Introdução}

A Segunda Conferência Geral do Episcopado Latino-Americano, ocorrida em Medellín, foi um evento que suplantou o ambiente eclesial da América Latina, indo muito além daquilo que poderia ser considerada uma reunião de religiosos para discutir os rumos da Igreja Católica em seu continente. Cercada por um contexto delicado, do ponto de vista social, político, econômico e religioso, a conferência de Medellín pode ser vista como um reflexo de mudanças de posicionamento da Igreja Católica, em relação à própria sociedade, fruto do Concílio Vaticano II e de movimentos populares que a antecederam e ganharam força com o próprio concílio. A força do texto produzido pelos bispos latino-americanos pode ser vista como um arrojado brado contra as árduas situações impostas aos povos mais pobres dos países latino-americanos, em decorrência de opções econômicas e dos cenários políticos presentes em boa parte das nações latinas.

Quando o Papa João XXIII publicou a convocação para o Concílio Vaticano II, através da Constituição Apostólica Humanae Salutis, parecia buscar situar a Igreja em seu tempo:

Será esta uma demonstração da Igreja, sempre viva e sempre jovem, que sente o ritmo do tempo e que, em cada século, se orna de um novo esplendor, irradia novas luzes, realiza novas conquistas, permanecendo, contudo, sempre idêntica a si mesma, fiel à imagem divina impressa em sua face pelo esposo que a ama e protege, Jesus Cristo. ${ }^{1}$

Ainda na mesma Constituição Apostólica, o sumo pontífice afirmava aguardar com esperança os frutos da empreitada conciliar. João XXIII não teve a oportunidade de ver concluído e implantado o concílio que convocara. Angelo

${ }^{1}$ HS 7. 
Roncalli faleceu em junho de 1963, deixando um legado que, mesmo não concluído por ele mesmo, traria profundas mudanças na vida da Igreja Católica. A tarefa de concluir os trabalhos capitaneados por João XXIII ficou sob a responsabilidade de Paulo VI. Antes de ser eleito como sucessor do Apóstolo Pedro, o Arcebispo de Milão, Cardeal Giovanni Battista Enrico Antonio Maria Montini, era visto como um bispo acautelado com o movimento conciliar logo no início das discussões propostas por João XXIII. ${ }^{2}$

O primeiro documento do Concílio Vaticano II a ser publicado, em dezembro de 1963, trazia consigo as tintas de renovação desejadas por João XXIII. A Constituição Conciliar Sacrosanctum Concilium trazia consigo o reconhecimento da necessidade do uso da língua local nas celebrações litúrgicas, a necessidade de adaptações para a índole e tradições de outros povos tanto na evangelização quanto na música sacra, sinalizando o modo com o qual a Igreja deveria enxergar as igrejas locais espalhadas pelo mundo. ${ }^{3}$

$\mathrm{O}$ movimento litúrgico, surgido na Bélgica no início do século XX e tendo como polo irradiador de novas ideias o Mosteiro Mont César, busca uma volta às origens, abandonando aquilo que poderia ser interpretado como elementos supérfluos nas celebrações litúrgicas. ${ }^{4} \mathrm{~A}$ forte adesão ao redor do mundo parece ter sido reforçada por Pio XII através de sua encíclica Mediator $D e i,{ }^{5}$ em que reconhecia o valor dos estudos do movimento litúrgico e, de certa forma, valorizava a presença do povo no corpo místico de Cristo-cabeça. Outros movimentos anteriores também marcaram a participação popular naquilo que poderia parecer exclusivo dos ministros ordenados.

A colaboração dos fiéis leigos no apostolado hierárquico, designado como Ação Católica, tomou uma tal dimensão a partir do pontificado do Papa Pio XI, que se tornou a designação própria de um grande movimento ramificado em diversos setores e atividades, sob a efígie de uma só bandeira: AÇÃO CATÓLICA. ${ }^{6}$

A necessidade de uma maior participação popular no seio da Igreja mostrava o quanto essa desconexão com o povo estava deixando a Igreja um tanto quanto apartada do próprio mundo. Uma série de movimentos anteriores ao Concílio marcaram profundamente os rumos dos debates e dos documentos

\footnotetext{
${ }^{2}$ ABREU, E. H.; SOUZA, N., Concílio Vaticano II, memória e esperança para os dias atuais, p. 96.

${ }^{3} \mathrm{SC} 37$.

${ }^{4}$ LIBANIO, J. B., Igreja Contemporânea, encontro com a modernidade, p. 51.

${ }^{5} \mathrm{MD} 4$.

${ }^{6}$ SOUZA, N., Ação Católica, militância leiga no Brasil, p. 39.
} 
produzidos pelos padres conciliares. O movimento Ecumênico ganhava força na Europa a ponto de, em 1949, o Santo Ofício reconhecer a inspiração do Espírito Santo em tal movimento. ${ }^{7} \mathrm{O}$ decreto Unitatis Redintegratio, que compõe o conjunto dos documentos produzidos pelo Concílio Vaticano II, fomenta o diálogo com outras Igrejas e Comunidades Eclesiais.

A influência do movimento bíblico resultou na Constituição Dogmática Dei Verbum (1965) e, por fim, houve um documento falando sobre a Igreja e o mundo, Gaudium et Spes. Os documentos conciliares que situavam a Igreja em seu tempo causaram impactos profundos no fazer teológico, no modo com o qual o diálogo com a realidade se dava, sobretudo, na participação popular.

Em 1969, W. H. van de Pol afirmava estar-se presenciando o "fim do Cristianismo convencional". Em obra amplamente difundida e muito utilizada por João Batista Libanio, Van de Pol afirmava que: "o convencionalismo eclesiástico 'está precipitando para o fim e que o novo, também em ritmo precipitado, está tomando formas diferentes daquelas que se esperavam" ". ${ }^{8}$ É fato que a chamada virada antropológica da Igreja faria com que os problemas do mundo tomassem conta das reflexões da própria Igreja. Desta vez, não de modo impositivo, mas propositivo, como afirma a Gaudium et Spes em seu número 4.

Nesta virada antropológica, pela primeira vez na história, em outubro de 1965, um papa discursava na Assembleia Geral das Nações Unidas e apresentava-se como "perito em humanidade". Em anos anteriores, tal visita ou mesmo tal discurso seria impensável visto a ruptura de muitos antecessores do Papa Paulo VI com a então chamada modernidade. Cerca de cem anos separaram o divórcio da Igreja com o mundo, através da Encíclica Quanta Cura de Pio IX, seguida de sua reconciliação através do Concílio e dos posteriores documentos e ações de Paulo VI. A movimentação na Igreja pós-Concílio trouxe uma série de releituras que surgiram na esteira das proposições dos documentos conciliares. Muito da produção do magistério de Paulo VI buscava ajudar a compreensão das mudanças propostas e, até mesmo, trazer novas luzes ao modo com o qual as decisões tomadas no Vaticano II deveriam fazer parte da caminhada eclesial. Um dos exemplos mais claros deste novo modo de relacionar-se com o mundo pode ser verificado na Encíclica Populorum Progressio, cujo tema central é o desenvolvimento dos povos e os abismos formados pelo esquecimento daqueles que foram impedidos de seguir em frente na torrente desenvolvimentista. Temas como fome, trabalho precário, racismo, imigrantes, juventude, solidariedade e, até mesmo, os nacionalismos

${ }^{7}$ LIBANIO, J. B., Igreja Contemporânea, encontro com a modernidade, p. 75. 
transpassam o documento que se mostra surpreendentemente atual. Portanto, a Igreja, segundo Paulo VI, deveria ser advogada dos povos pobres.

\section{Contexto político latino-americano da Conferência de Medellín}

Enquanto a Igreja parecia viver um clima primaveril com os ventos do Vaticano II e as viagens de Paulo VI ao redor do mundo, a situação política na América do Sul não mostrava sinais de Evangelho sendo vivido. Muito pelo contrário, as sucessivas ditaduras militares aconteciam pelos países do continente e mostravam, na prática, toda a contrariedade ao Evangelho de Jesus Cristo. Para que se tenha uma melhor compreensão da dimensão da força da onda de autoritarismo, basta focar em três países do cone sul: Paraguai, Argentina e Brasil passavam, nos anos 60, por severas ditaduras militares.

\subsection{Paraguai}

No Paraguai de 1954, Alfredo Stroessner governava, com mão pesada, um país marcado por uma abissal desigualdade social. Sustentado por um "autogolpe", um elaborado culto à personalidade do ditador, sequentes eleições cercadas de suspeitas de fraudes, sistemática eliminação de seus oponentes e, capitaneando o principal partido no país, o governo ditatorial do General Stroessner era conhecido por sua crueldade, posteriormente revelada pelos chamados Arquivos do Terror, encontrados em uma delegacia próxima de Assunção em 1992. ${ }^{9}$ Os Arquivos do Terror revelam em pormenores a violência da ditadura de Stroessner, como os desaparecimentos e apropriações de crianças daqueles denominados subversivos por se oporem Alfredo Stroessner. ${ }^{10}$

\subsection{Argentina}

Em seu texto "Os três tipos puros de dominação", Max Weber fala da força de uma liderança carismática (charismatische herrschaft) como modo de dominação em uma estrutura social. ${ }^{11}$ Talvez Alfredo Stroessner tenha seguido a cartilha weberiana, mas o caso de líder carismático não é exclusividade e nem premissa paraguaia. Juan Domingo Perón, que governou a Argentina por três mandatos, encarnou o líder carismático e criou, em âmbito argentino, uma tradição política tão personalista, que a mesma acabou sendo atribuída a seu

\footnotetext{
${ }^{9}$ VERA, M. G., "Data feliz" no Paraguai, p. 406.

${ }^{10}$ BARRETO, A. F. A. L., Arquivos do terror e stronismo, p. 152.

${ }^{11}$ WEBER, M., Sociologia.
} 
nome: o peronismo. E foi nos imbróglios do combate ao peronismo que se instalou na Argentina mais um dos sucessivos golpes militares ocorridos no país durante o século. ${ }^{12}$

Com o golpe autodenominado revolução, o General Juan Organía, líder da ação, procurava "deixar claro que planejava permanecer um longo tempo na presidência ao invés de um período de transição até que novas eleições pudessem ser conclamadas". ${ }^{13}$ Esta não foi a última ditadura militar na Argentina, mais tarde, no final dos anos 70, outra ditadura governaria o país, nesta ocasião, promotora de um modelo econômico neoliberal que tomaria conta da América Latina.

\subsection{Brasil}

O Brasil, maior país da América Latina, também vivia fortes instabilidades de governos. Desde Getúlio Vargas, o país jamais passara por um momento de longa estabilidade no âmbito do governo federal. Em 1961, eleito como uma versão brasileira da charismatische herrschaft weberiana, o demissionário Jânio da Silva Quadros chegou à presidência do Brasil com características que chamam a atenção:

O tom de sua campanha política era música para os ouvidos da UDN: ataques à corrupção, à inflação, à alta do custo de vida, ao desperdício de dinheiro com as obras monumentais de Brasília, acompanhados de promessas de crescimento econômico, austeridade pública e contenção de gastos. Jânio jamais explicou de maneira convincente como iria superar os limites do governo de Kubitscheck ou atacar os problemas fundamentais do desenvolvimento brasileiro. Sua mensagem era antipolítica. ${ }^{14}$

A renúncia de Jânio Quadros, no mesmo ano de sua posse, causou uma convulsão social sem precedentes, foram "talvez os dois anos e meio mais turbulentos na história moderna do Brasil". ${ }^{15}$ Abrindo mão do poder, Jânio Quadros deixava para João Goulart a tarefa de governar o país, e o mesmo, virando-se para o espectro político à esquerda, foi taxado de comunista $\mathrm{e}$ acusado de desejar minar a democracia. A resposta veio com o golpe militar e, em primeiro de abril de 1964, o Brasil acordava sob um regime militar que

\footnotetext{
${ }^{12}$ BETHELL, L., Historia de América Latina, p. 108.

${ }^{13}$ HEDGES, J., Argentina, p. 280.

${ }^{14}$ SCHWARCZ, L. M.; STARLING, H. M., Brasil, p. 265.

${ }^{15}$ ROHTER, L., Brazil on the rise, the story of a country transformed, p. 13.
} 
depusera João Goulart, através de uma manobra orquestrada por militares e parte do congresso nacional. A ditadura militar brasileira tratou de coibir violentamente todos aqueles que poderiam se opor ao novo regime. Já, em seus primeiros lances, Ernesto Geisel e Golbery Couto Silva participaram, "em 1964, de um aparelho repressivo incapaz de conviver com um regime constitucional. Geisel, colocado por Castello na chefia do Gabinete Militar da Presidência, estava no olho do furacão da usina de punições políticas instalada no amanhecer do regime". ${ }^{16}$

\section{A Conferência de Medellín e o Capítulo da Paz}

Brasil, Argentina e Paraguai podem servir como um recorte amostral do que era a situação política na América Latina às vésperas da realização da Segunda Conferência Geral do Episcopado Latino-Americano, que seria realizada na Colômbia, em Medellín. A força avassaladora do Concílio Vaticano II chegava à América Latina. Era tempo de fazer com que o Concílio terminado em Roma fosse reaberto em âmbitos diocesanos e igrejas locais. ${ }^{17} \mathrm{~A}$ preparação para Medellín tomou cerca de dois anos e, na Argentina, em meio à ditadura nascente de Organía, acontecia uma das principais reuniões preparatórias, em que se discutiu:

Sobre os problemas urgentes do subdesenvolvimento na América Latina (...). Nessa ocasião, mais do que os relatórios apresentados e discutidos nas reuniões plenárias, contribuíram ao crescimento da sensibilidade geral do Episcopado Latino-Americano sobre os problemas da situação de subdesenvolvimento e da pobreza estrutural do continente. ${ }^{18}$

A participação da Igreja nos debates sobre os problemas sociais na América Latina foi sendo animado pelas resoluções conciliares e pela Populorum Progressio. A já conhecida repressão violenta dos regimes ditatoriais parecia abafar os movimentos sociais com suas pautas e reivindicações. No entanto, a Igreja Católica poderia ser uma voz pelos sem voz, exercendo, portanto, sua vocação profética. No Brasil, em 1966, os bispos do Regional Nordeste II $^{19}$ denunciavam as injustiças cometidas contra

\footnotetext{
${ }^{16}$ GASPARI, E., A Ditadura Envergonhada, p. 132.

${ }^{17}$ SCATENA, S. A., Compêndio das Conferências dos bispos da América Latina e Caribe, p. 73.

${ }^{18}$ SCATENA, S. A., Compêndio das Conferências dos bispos da América Latina e Caribe, p. 73.

${ }^{19}$ Circunscrição Eclesiástica ligada à CNBB que reúne as Igrejas no Pernambuco, Paraíba, Rio Grande do Norte e Alagoas.
} 
trabalhadores e apoiavam organizações sindicais e movimentos de representação de trabalhadores rurais. A defesa dos direitos humanos tornavase linha de ação da Igreja Católica no maior país da América Latina. ${ }^{20}$ Em 24 de agosto de 1968, o Papa Paulo VI inaugura a Segunda Assembleia do CELAM, conclamando os bispos a não deixarem de lado seu olhar pelas questões sociais e trazendo um importante relevo ao tópico da paz, um dos eixos principais de seu pontificado.

Pues bien, aquí, durante La celebración del sacramento eucarístico, símbolo y fuente de unidad y de paz, repetimos nuestros augurios por la paz; la paz verdadera que nace de los corazones creyentes y fraternos; la paz entre las clases sociales en la justicia y en la colaboración; la paz entre los pueblos mediante un humanismo iluminado por el Evangelio; la paz de América Latina; vuestra paz. ${ }^{21}$

De fato, o tema da paz toma uma grande parte na redação final das resoluções de Medellín. O segundo capítulo dedica-se todo ao tema, e o conteúdo de seu texto não serve tão somente a um clamor profético pela paz, mas se utiliza dele como forma de denúncia de uma série de injustiças que impedem a vivência de uma paz verdadeira ao povo latino-americano. As resoluções conciliares e a encíclica Populorum Progressio podem ser consideradas a base para as resoluções de Medellín. O capítulo da paz abre fazendo memória à Populorum Progressio ao afirmar que o desenvolvimento é o novo nome da paz, conforme o preâmbulo da conclusão da encíclica de 1967.

Utilizando-se do mote proposto por Paulo VI, os bispos do CELAM formulam um texto que aponta para o binômio justiça e paz, cuja formulação está no Salmo 85, mas é também trabalhado nos documentos conciliares e na Populorum Progressio. Ao lançar o olhar para as diversas situações sociais, por meio deste binômio, surge uma lista de injustiças sociais facilmente verificáveis na quase totalidade dos países da América Latina. Quando os bispos afirmam que não desejam somente fazer um apanhado geral sobre as situações sociais dos povos latino-americanos, mas sim assumir sua função de denunciar e chamar a atenção para fatores que ameaçam ou, até mesmo, negam possibilidades de uma vida em paz, reforçam o tom profético do documento.

Dividido em duas partes com três subdivisões cada, o capítulo da paz é provocativo quando confrontado com as realidades vigentes na América Latina. $\mathrm{Na}$ primeira parte, sem se resguardar em trabalhar a transformação social

${ }^{20}$ DELGADO, L. D. A. N.; PASSOS, M., Catolicismo, p. 113.

${ }^{21}$ PAULO VI, PP., Inauguración de la II Asamblea General de los Obispos de America Latina. 
impulsionada pela fé em Jesus Cristo, os bispos latino-americanos falam abertamente de tensões de classes, colonialismos internos e externos, intervenção internacional em políticas nacionais e a perda de uma identidade latino-americana, o que poderia contribuir para uma eclesiologia partindo da história e da vida de fé dos povos da América Latina. A segunda parte do capítulo fala da concepção cristã da paz, servindo como um estágio do julgar, dentro do método ver-julgar-agir; passa, novamente, por um olhar pelas situações que atentam contra a paz dos povos latino-americanos e, conclui, com uma terceira seção, dando sugestões e pistas pastorais de ação. Ao falar das marginalizações e seus diversos aspectos, na abertura da seção sobre o Colonialismo Interno, o texto de Medellín lembra das questões socioeconômicas e das desigualdades excessivas entre classes sociais.

As situações sociais que contextualizam o texto de Medellín se relacionavam às ações econômicas liberais dos países latino-americanos. Em 1968, por exemplo, o Brasil viveu o início de um próspero momento econômico, após um duro quadro recessivo implantado pelo governo do General Castelo Branco no início da ditadura militar. Com um crescimento do Produto Interno Bruto (PIB) chegando aos dois dígitos, o Brasil parecia viver seu milagre econômico em consonância com uma onda de crescimento que acontecia em boa parte da economia mundial. ${ }^{22}$ Segundo Prado e Earp, tal crescimento não foi fator de distribuição de renda, muito pelo contrário, o censo de 1970 demonstrou que a distribuição de renda havia piorado no país. Em 1972, o Brasil chegou a ser alvo de críticas do Banco Mundial por essa deficiência. Assim, o clamor de Medellín encontrava eco na situação econômica dos mais pobres no Brasil. Em território argentino, a situação era estável do ponto de vista econômico, as taxas de desemprego eram baixas $(5,8 \%)$ e a entrada do capital estrangeiro trazia novas configurações para a economia argentina que saía, na segunda metade da década de 1960 , de uma recessão até então histórica. ${ }^{23}$ A situação paraguaia era de aparente bonança, fruto do crescimento econômico resultante da construção de usina hidrelétrica de Itaipu e da entrada de capital internacional. Entretanto, de acordo com Leslie Bethell, o bem-estar propagado por Stroessner era algo muito particular aos donos de grandes propriedades, aos investidores e participantes dos altos cargos governamentais; a situação geral do povo era de erosão do nível de vida, com aumentos salariais abaixo daquilo que era a reposição dos preços segundo a inflação.

${ }^{22}$ PRADO, L. C. D.; EARP, F. S., O “milagre” brasileiro, p. 227.

${ }^{23}$ PORTANTIERO, J. C., Economía y política en la crisis argentina, p. 554. 
Dessa forma, os pobres sofriam as consequências das várias intervenções econômicas liberais na América Latina, nas décadas de 1960 e 1970. A situação socioeconômica tinha números aparentemente promissores, mas o cenário socioeconômico dos trabalhadores da cidade e do campo, que formavam a camada mais pobre da população, não era um retrato fiel da alardeada prosperidade econômica. As denominadas opressões de grupos, pelos setores dominantes, eram uma realidade perfeitamente verificável no cenário latinoamericano. As ditaduras militares não eram brandas com seus opositores que, muitas vezes, classificavam os que se colocavam contra a violência praticada pelo Estado, no grupo dos subversivos, como denuncia o próprio texto dos bispos. Em meio ao governo do General Castello Branco, "numa feira de livros de Niterói apreenderam-se exemplares da encíclica Mater et magistra, do papa João XXIII". ${ }^{24}$ Mais tarde, a Igreja seria transformada em local de encontro para discussões sobre o AI- $5^{25}$ e reflexões sobre a violência do Estado contra trabalhadores, nos âmbitos rurais e urbanos.

O palco de debates e mobilizações contra a injustiça social e a doutrina de segurança nacional, particularmente depois do AI-5, eram as CEBs. Diversas vozes e mobilizações resistiram às imposições. A contribuição das CEBs se fazia sentir nas denúncias de violência no campo, nas fábricas e no movimento estudantil. Diversos grupos que não tinham outro espaço integraram-se na pastoral popular. ${ }^{26}$

Nesta ocasião, na Argentina, o cenário era de eclosão de lideranças que começavam a questionar Organía e as consequências de seu governo que deixava de lado os mais pobres, os operários e agricultores. Uma série de conflitos e reivindicações no interior industrial do país resultaram em uma nova geração de líderes sindicais e de comissões de trabalhadores imbuídos de ideologias de espectro político mais à esquerda. Ao utilizar todo o expediente governamental e jurídico para transformar Juan Perón em um cadáver político, Organía minou os partidos opositores e uma nova oposição nascia sem organização política buscando espaço até mesmo por atitudes violentas como guerrilhas urbanas. ${ }^{27}$ A situação de repressão paraguaia também era violenta e

\footnotetext{
${ }^{24}$ GASPARI, E., A Ditadura Envergonhada, p. 221.

${ }^{25}$ Ato Institucional Número 05, dispositivo utilizado pela ditadura militar brasileira para formular leis anticonstitucionais. O AI-5 foi publicado pelo General Artur da Costa e Silva, em 13 de Dezembro de 1968.

${ }^{26}$ DELGADO, L. D. A. N.; PASSOS, M., Catolicismo, p. 124.

${ }^{27}$ BETHELL, L., Historia de América Latina, p. 108.
} 
gerava um clima de perseguição entre os próprios cidadãos, como relata Miguel H. López em seu trabalho Stroessner e "Eu":

Ligado ao funcionamento do partido como órgão de controle social, o governo fomentou a cultura de traição e denúncia. Os pyrague constituíam um exército de espionagem do cidadão. Nada nem ninguém escapava a eles. Muitas vezes intrigavam ou difamavam para congraçar-se com o ditador ou resolver problemas pessoais pela via do castigo que o regime impunha a seus detratores. Com a acusação de comunistas - fiel ao discurso de Stroessner - estigmatizavam quem não comungava com o sistema ou militava em grupos opositores. ${ }^{28}$

Ao falar das tensões externas e do neocolonialismo externo, o documento de Medellín faz memória concreta sobre como o processo colonizador ainda não havia sido concluído na América, que é detentora de recursos naturais inestimáveis. Neste sentido, a Floresta Amazônica é vista como um patrimônio, não só pela diversidade biológica nela contida, mas pela riqueza aparentemente inesgotável de bens naturais ainda desconhecidos. A exportação de alimentos era e ainda é um dos principais meios de comércio com o mercado mundial e a especulação financeira se torna uma forma de domínio sobre exportadores. Ao transformar alimentos em categoria de comércio, como commodities, os importadores abrem brechas para que possam exercer poder de barganha comercial superior ao produtor. Medellín cita a encíclica Populorum Progressio ao afirmar a crescente exploração internacional dos países industrializados, a qual hoje possui outra nomenclatura e, lamentavelmente é aceita sob o verniz da chamada especulação financeira. A sanha financeira é motivo de preocupação dos bispos latino-americanos endossados por Paulo VI e Pio XI ao citarem o "imperialismo internacional do dinheiro". ${ }^{29}$

A questão econômica na América Latina sob forte influência internacional é um ponto a ser observado tanto pela ótica da denúncia dos bispos em Medellín quanto por um movimento criado pela Escola Econômica de Chicago (de viés ultraliberal) em terras latino-americanas.

Como todas as formas de fé fundamentalista, a Escola de Economia de Chicago representa, para seus seguidores, um circuito fechado. A premissa fundamental é a de que o livre mercado é um sistema científico perfeito, no qual os indivíduos, agindo em função de seus próprios interesses e desejos, criam o máximo benefício para todos. Se alguma coisa dá errado

${ }^{28}$ LÓPEZ, M. H., Stroessner e “Eu”, p. 440.

${ }^{29} \mathrm{DM}, \mathrm{A}$ Paz, 9. 
em uma economia de livre mercado - inflação alta ou desemprego crescente - é porque o mercado não está verdadeiramente livre. ${ }^{30}$

Em oposição aos modelos econômicos desenvolvimentistas ou sociaisdemocratas presentes especialmente no Cone Sul, cujo principal vetor era o CEPAL de visão econômica provinda de Harvard, Yale e Oxford, a Escola Econômica de Chicago via o desenvolvimento de países sul-americanos como um perigo para o livre mercado em vista do incômodo do intervencionismo tão indesejado pelo assim chamado livre mercado.

Como em uma visão religiosa já descrita por Naomi Klein, era necessário criar uma rede global de entidades que ajudassem a formar um pensamento que disseminaria o ultraliberalismo econômico. "A contrarrevolução da Escola de Chicago pretendia eliminar todas as formas de proteção que os trabalhadores haviam conquistado e todos os serviços públicos que o Estado oferecia com o objetivo de aparar as arestas do mercado". ${ }^{31}$ As economias de modelo desenvolvimentista representavam um perigo para o livre mercado e, eram vistas como um inimigo a ser combatido pelos outrora doutrinados pela Escola de Chicago. Na visão da Escola de Chicago, o modelo econômico adotado na maioria dos países do Cone Sul era pernicioso para o capitalismo, chegando a chamar de "vermelhos" os economistas atuantes na América do Sul.

A solução pela formação de novos economistas alinhados a um pensamento econômico liberal aos moldes de Chicago veio através da Universidade Católica do Chile, que acolheu o "Projeto Chile" com a intenção explícita de implantar o modelo liberalista em oposição ao modelo econômico desenvolvimentista presente na América Latina. ${ }^{32}$ Entre as décadas de 1950 e 1970, com bolsas pagas pelos contribuintes e fundações estadunidenses, alunos do Brasil, Argentina e México também foram formados pelo pensamento religioso do Departamento de Economia da Universidade de Chicago: "Doutrinar os visitantes na ortodoxia da Escola de Chicago tornou-se uma prioridade urgente". ${ }^{33}$ A doutrinação imperiosa no campo de vista econômico era o retrato do imperialismo ideológico e político vigente na América Latina. A orquestração para que se pudesse sufocar qualquer indício de um sistema econômico que não fosse o capitalismo liberal funcionou como uma espécie de nova colonização aos países latinos.

${ }^{30}$ KLEIN, N., A doutrina do choque, p. 67-68.

${ }^{31}$ KLEIN, N., A doutrina do choque, p. 73.

${ }^{32}$ KLEIN, N., A doutrina do choque, p. 77.

${ }^{33}$ KLEIN, N., A doutrina do choque, p. 77. 
No terceiro tópico da primeira parte, o documento A Paz em Medellín aborda as tensões entre os países da América Latina apontando dois aspectos importantes para tais tensões: o nacionalismo exacerbado e o armamentismo. A missão de fazer com que o Concílio Vaticano II acontecesse na América Latina e o uso da Populorum Progressio como roteiro principal desta tarefa, especialmente pelo conteúdo social em uma realidade que clamava uma ação social mais abrangente por parte da Igreja, fez com que o tema do nacionalismo abordado por Paulo VI em sua encíclica fosse também contemplado no texto de Medellín. O pontífice coloca o nacionalismo pós-guerra como um obstáculo a ser vencido em nome de uma cultura que destrua o isolamento das nações e para que se possa construir uma sociedade mais integrada e solidária.

Para o ambiente latino-americano, a questão nacionalista, em muito, deixa de lado uma cultura anterior à colonização europeia. Antes mesmo dos países possuírem as subdivisões impostas por Espanha e Portugal, havia uma terra latino-americana, onde os povos ancestrais possuíam identidade definida, civilizações organizadas e, portanto, um arcabouço cultural distante de ser parco em sua produção.

Y mientras Latinoamérica no encuentre su lugar en la historia universal de las culturas, nuestras culturas nacionales serán como frutos sin árbol, como nascidas por generación espontánea. Un cierto "nacionalismo" cultural nos lanzó al encuentro de lo nacional. ¡Es necesario dar un paso adelante y descubrir Latinoamérica para salvar nuestra misma cultura nacional! Es necesario, entonces, superar dicho nacionalismo. ${ }^{34}$

As afirmações de Enrique Dussel encontram paralelismo com o pensamento dos bispos em Medellín. A desejada paz fruto da justiça, não vivida pelos povos latino-americanos, poderia contar com o elemento cultural como catalisador dos anseios desses povos na busca de uma identidade latinoamericana e consequentemente, resultar em um modelo de Igreja latinoamericano que não fosse uma mimetização de outros modelos eclesiais. Essa superposição cultural europeia ${ }^{35}$ também retirou características eclesiais que enriqueciam o seguimento de Jesus Cristo, de acordo com as características dos povos latino-americanos. A colonização não aconteceu somente no campo sociocultural, mais tarde, ela também viria no âmbito religioso.

O nacionalismo exacerbado era característico das ditaduras. No Brasil, por exemplo, enquanto o governo ditatorial do General Médici exterminava,

${ }^{34}$ DUSSEL, E., Filosofia de la cultura y la liberacion, p. 113.

${ }^{35}$ DM, Justiça, 1. 
sequestrava e prendia, aos borbotões, àqueles que se colocavam como opositores do regime, alardeava as grandezas nacionais com slogans como "Ninguém segura esse país" ou "Brasil, ame ou deixe-o!". No Paraguai, a exaltação da nação era ligada diretamente ao próprio General Stroessner, enquanto na Argentina, o artífice maior do nacionalismo foi Juan Perón que, embora não fosse um ditador de fato, mas um populista renomado, governou a Argentina em três ocasiões.

O discurso contra as armas também trazia consigo uma forte crítica ao modo com o qual os governos mantinham suas nações sob controle. Ao citar uma corrida armamentista que ultrapassa o limite do razoável, ${ }^{36}$ os bispos fazem eco não somente à Populorum Progressio, mas também ao discurso de Paulo VI na ONU.

Se vós quereis ser irmãos, deixai cair as armas das vossas mãos. Não se pode amar com armas ofensivas nas mãos. As armas, sobretudo as terríveis armas que a ciência moderna vos deu, antes mesmo de causarem vítimas e ruínas, engendram maus sonhos, alimentam maus sentimentos, criam pesadelos, desconfianças, sombrias resoluções. Exigem enormes despesas. Detêm os projetos de solidariedade e de útil trabalho. Falseiam a psicologia dos povos. ${ }^{37}$

O discurso armamentista e a atitude bélica dos governantes ditadores na América Latina eram, de fato, uma afronta ao próprio Evangelho. A violência de estado era praxe no controle populacional, os armamentos eram sinais dessa força repressora. Enquanto os índices de desenvolvimento humano eram precários, a corrida armamentista era incrementada mostrando a opulência do estado. O armamentismo poderia ser visto como a ponta visível de um sistema perverso de violenta perseguição política. Mesmo após a publicação do texto de Medellín, o Papa Paulo VI continuava olhando ciosamente para a situação da violência no Brasil, a ponto de pedir algum desmentido sobre as torturas policiais ocorridas no Brasil. ${ }^{38}$

No documento de Medellín, a segunda parte do capítulo dedicado à paz traz consigo uma recordação da concepção cristã da paz. Ao relembrar novamente o binômio justiça e paz partindo da Gaudium et Spes, o texto relembra que a justiça que resultará na paz cristã é aspiração humana. Recordando as palavras de Paulo VI em sua mensagem de ano novo

\footnotetext{
${ }^{36} \mathrm{DM}, \mathrm{A}$ Paz, 13.

${ }^{37}$ PAULO VI, PP., Discurso de Paulo VI na sede da ONU.

${ }^{38}$ GASPARI, E., A Ditadura Escancarada, p. 283.
} 
(01/01/1968), o texto de Medellín traz o apelo de que todas as injustiças elencadas ao longo do capítulo sejam consideradas atentados diretos contra a paz. A paz desejada pelos governantes e pelos colonizadores não é a paz cristã, imputada por uma cultura do medo, ela cria ambientes nos quais resoluções antes impensadas tornem-se (pelo medo imputado) necessárias para que "o grande mal" não se instale. ${ }^{39} \mathrm{~A}$ paz tem um novo nome, de acordo com os bispos latino-americanos:

Não se consegue a paz senão criando uma ordem nova que "comporte uma justiça mais perfeita entre os homens" (PP 76). Nesse sentido, o desenvolvimento integral do homem, a passagem de condições menos humanas para condições mais humanas é o nome novo da paz. ${ }^{40}$

Contudo, é na segunda parte do capítulo que o texto mais contundente sobre a paz é apresentado. Baseado, em grande parte, nos discursos de Paulo VI em Bogotá e na Populorum Progressio, os bispos reafirmam a defesa dos empobrecidos e falam abertamente sobre a violência na América Latina. Com sabedoria cristã, os bispos latino-americanos recordam que o amor evangélico deve ser a base de pensamento dos que creem e uma cultura de paz deve ser um ato de fé. Mas o apelo aos cristãos vai além de um recordar de consciência, o apelo para a necessidade de justiça como veículo para a construção da paz é retomado em todos os momentos. No entanto, é partindo do princípio das injustiças instauradas e quase normalizadas que o documento assume uma posição aguerrida. Os bispos chegam a falar (citando Paulo VI em Bogotá) de "revoluções nascidas do desespero" frente às metodologias violentas de manutenção de poder e privilégios, vistos em muitos países latino-americanos. "Não se deve abusar da paciência de um povo que suporta durante anos uma condição que dificilmente aceitaria os que têm maior consciência dos direitos humanos". ${ }^{41}$

À altura da redação de Medellín, quantos possuidores de conhecimento dos direitos humanos não sucumbiram à pesada mão das ditaduras, por terem a paciência esgotada frente as sistemáticas violências promovidas pelo estado? De maneira arrojada, o documento assume a possibilidade de que um cristão ligado à Igreja saia da passividade, em oposição direta às injustiças derivadas das violências empregadas para a manutenção de privilégios.

\footnotetext{
${ }^{39}$ ALBRIGHT, M., Fascismo, p. 16.

${ }^{40} \mathrm{DM}, \mathrm{A}$ Paz, 14.

${ }^{41}$ DM, A Paz, 16.
} 
Dirigimos-lhes, pois, um apelo urgente a fim de que a posição pacífica da Igreja não seja invocada pela oposição, passiva ou ativa, para opor-se às transformações profundas que são necessárias. Se mantiverem zelosamente seus privilégios e sobretudo, se os defenderem com o emprego de meios violentos, tornam-se responsáveis, perante a história, por provocar as "revoluções nascidas do desespero" (Discurso de Paulo VI, em Bogotá, na celebração eucarística do Dia do Desenvolvimento, 23 de agosto de 1968). De sua atitude depende, portanto, em grande parte, o pacífico porvir dos países da América Latina. ${ }^{42}$

Apesar da dureza do discurso, os bispos recordam, no desenrolar do texto, que novas tiranias costumam surgir das revoluções que começam de maneira nobre. A força do texto está em observar com clareza os cenários vigentes à época e tratá-los de maneira direta. $O$ texto não isenta ninguém que detenha algum tipo de responsabilidade constituída pela luta contra as injustiças. A omissão também é apontada de maneira clara como alimentadora da máquina da injustiça. A visão cristã da paz, sugerem os bispos, não gera uma passividade e nem um anular de indignações, muito pelo contrário. No entanto, as energias de indignação frente às injustiças não podem ser colocadas em favor da violência, mas por um trabalho árduo pela busca da justiça e da paz, na luta, na construção deste projeto.

As conclusões pastorais do capítulo apontam para linhas também inovadoras e com um forte apelo para a inserção dos cristãos em instâncias de lutas por direitos. Apesar de o capítulo tratar da paz, os bispos conclamam os povos a tomarem consciência da justiça e, a defenderem o direito dos pobres e oprimidos instando governantes a eliminarem aquilo que destrói a paz social. $\mathrm{O}$ documento também pede que as pregações e catequeses estejam sintonizadas com as realidades sociais e não percam o espírito crítico. $\mathrm{O}$ discurso contra a corrida armamentista também retorna nas indicações pastorais, lembrando que a guerra a ser travada é a guerra contra a miséria, recordando também a importância da declaração universal dos direitos humanos.

\section{Conclusão}

A primavera do Concílio Vaticano II por Paulo VI, um papa que esteve nos trabalhos e compreendeu o espírito conciliar foi vivida intensamente no continente latino-americano. O clamor por uma Igreja em diálogo com a

${ }^{42}$ DM, A Paz, 17. 
sociedade, propositiva, acolhedora e advogada dos mais necessitados encontrou solo fértil entre os bispos da América Latina.

As situações sociais e políticas no continente, em especial nos países do Cone Sul, clamavam por uma voz que assumisse a voz dos empobrecidos, daqueles que viviam perseguidos e colocados à margem, por se oporem aos regimes e sistemas que priorizavam as elites e o lucro indiscriminado. A forte influência da economia norte americana e de modelos econômicos liberais traziam chagas profundas na vida dos mais simples, impossibilitados de participar da dinâmica de vida arregimentada em torno do capital e não da vida das pessoas.

Os índices de pobreza, violência e a repressão do Estado eram temas cotidianos na vida do povo. Os resultados alardeados como sucesso do sistema implementado pelos governos ditatoriais não eram verificados na dura vida do povo, com o qual a Igreja se propunha a estar em contato direto. Números posteriores ao texto de Medellín demonstraram o quanto o documento era, além de profético, fincado na árdua vida dos mais simples.

Ao falar de paz, o documento retoma o assunto da justiça abordado no início do texto e, faz uso da questão da paz para apontar o quanto a vida dos pobres latino-americanos é tolhida de paz por causa das inúmeras injustiças impetradas em suas vidas. Ao assumir o papel de porta-voz dos empobrecidos e oprimidos, a Igreja latino-americana tomou para si o direito de advogar, como dizia Paulo VI, pelos últimos. Ao não se permitir associar aos governos, e sim aos pobres, os bispos decidiram viver a radicalidade do Evangelho e da encarnação de Jesus Cristo.

A produção teológica produzida na América Latina no período pósMedellín, esteve intimamente ligada às resoluções das Igrejas locais latinoamericanas. A teologia da libertação, uma reflexão teológica a partir do rosto dos pobres, utilizava como base, em todas as suas produções, a identificação do povo latino-americano e suas condições de vida muitas vezes precárias com a situação histórica do próprio Jesus Cristo e, partindo daí, construía um discurso teológico cuja principal característica era dar voz a estes anseios. É importante lembrar que o documento de Medellín já colocava o marxismo como elemento polarizador contra o capitalismo liberal e, lamentava o fato dos países latinoamericanos estarem colocados em meio a estas duas opções que, ao ver dos bispos, atentavam contra a dignidade da pessoa humana. As acusações que ligam toda a Teologia da Libertação a uma leitura marxista da realidade soam como uma tentativa de calar a voz dos profetas.

Cerca de meio século depois de Medellín, algumas realidades históricas de 1968, que pareciam distantes e meras lembranças, parecem retornar ao cenário 
latino-americano. No Paraguai, o filho do secretário particular de Alfredo Stroessner é o atual presidente do país. Mario Abdo Benítez coloca-se como um conservador e defensor de um stronismo sem a violência de Stroessner e, promete manter uma política econômica que garantiu crescimento ininterrupto, mas que continua sem solucionar o fato de que um terço de sua população está na linha da pobreza, números compostos em sua maioria por indígenas. ${ }^{43}$

Os números da pobreza Argentina não são diferentes, 27 em cada 100 cidadãos argentinos vivem na pobreza. Uma atual crise econômica está sendo combatida com os ensinamentos da Escola de Chicago, as chamadas soluções monetaristas. Nunca saudosos de sua ditadura, os Argentinos apostaram em um capitalista liberal que, em três anos, não conseguiu estabilizar a economia. Mauricio Macri, quando presidente, enfrentou pressões internas com greves espalhadas pelo país e dívidas assumidas com o Fundo Monetário Internacional. ${ }^{44}$

O Brasil tem como seu atual presidente um militar reformado que coleciona declarações misóginas, preconceituosas e sectárias; colocou-se favorável à tortura em muitas ocasiões, tanto que tem como livro de cabeceira uma obra escrita por um dos maiores torturadores da ditadura militar no Brasil. O presidente do Brasil tem como guru econômico um representante da Escola de Economia de Chicago, mostrando que o projeto de liberalismo econômico dos anos 1950 continua forte.

E a Igreja Católica na América Latina? Mantém a força de denúncia contra as injustiças que tinha em 1968? Os projetos assumidos estão voltados aos que continuam sofrendo diuturnamente com sistemas que trazem um rastro de pobreza consigo? A violência velada ou explícita imposta aos pobres é denunciada e combatida de maneira ferrenha? As denúncias contra o sistema marxista estão em pé de igualdade em relação às denúncias contra o capitalismo liberal? A dureza das palavras na defesa dos direitos humanos é discurso presente na atuação de bispos e padres? Há um favorecimento para que movimentos populares tomem conhecimento de sua situação e lutem por um sistema mais justo? A produção teológica é questionadora quanto ao colonialismo, transformadora e libertadora de acordo com a identidade latinoamericana? A formação laical e sacerdotal contempla a necessidade de uma vida de acordo com a pessoa de Jesus Cristo e a atualização de sua mensagem de maneira integral? ${ }^{45}$

${ }^{43}$ CUÉ, C. E.; CARNERI, S., Paraguai, o milagre silencioso e desigual.

${ }^{44}$ ENCARNACIÓN, O. G., Mauricio Macri was supposed to be different.

45 PEREIRA, S. C., O legado da "Igreja dos Pobres". 
A história parece repetir alguns aspectos na geopolítica latino-americana. É necessário que a Igreja possa recordar seu papel, que possa construir a paz através de ações que sejam arrojadas em seu tempo. Medellín foi um evento que marcou um modelo eclesial transformador, sem perder a identidade cristã católica. O Papa Francisco, primeiro latino-americano a assumir a função de sucessor de Pedro, traz consigo o jeito latino-americano de ser Igreja e pode servir de incentivo para que possamos recordar quem somos e o que podemos fazer pelo Reino de Deus e sua justiça, especialmente por aqueles mais identificados a Jesus Cristo, os que têm fome e sede, os refugiados, encarcerados, os empobrecidos, todos aqueles que precisam ter seus clamores ouvidos. Que a Igreja seja advogada dos pobres, como disse Paulo VI, que ela seja a voz dos sem voz, como afirmou Dom Oscar Romero, pois as urgências parecem continuar as mesmas e a história tem seus olhos também em nós.

\section{Referências bibliográficas}

ABREU, E. H.; SOUZA, N. Concílio Vaticano II, memória e esperança para os dias atuais. São Paulo: Paulinas, 2014.

ALBRIGHT, M. Fascismo: um alerta. São Paulo: Planeta, 2018.

BARRETO, A. F. A. L. Arquivos do terror e stronismo: memória, história e luto. Quaestio Iuris, v. 9, p. 140-163, 2016.

BETHELL, L. Historia de América Latina. Barcelona: Critica, 2002. v.15.

CELAM. Conclusões de Medellín. São Paulo: Paulinas, 1968. Disponível em: $<$ http://www.clerus.org/clerus/dati/2009-01/09-13/medellin.html $>$. Acesso em: 16 nov. 2018.

CONCÍLIO VATICANO II. Constituição Conciliar Sacrosanctum Concilium. Vaticano: [s.n.], 1963.

CUÉ, C. E.; CARNERI, S. Paraguai, o milagre silencioso e desigual. Eı País, Assunção, 21 abr. 2018. Disponível em: $<$ https://brasil.elpais.com/brasil/2018/04/19/internacional/1524157022_02577 3.html>. Acesso em: 16 nov. 2018.

DELGADO, L. D. A. N.; PASSOS, M. Catolicismo: direitos sociais e direitos humanos (1960-1970). In: FERREIRA, J.; DELGADO, L. D. A. N. O Brasil Republicano: o tempo da ditadura. Rio de Janeiro: Civilização Brasileira, 2007. p. 93-130. 
DUSSEL, E. Filosofia de la cultura y la liberacion. Mexico: Universidad Nacional Autonoma de Mexico, 2007.

ENCARNACIÓN, O. G. Mauricio Macri was supposed to be different. Disponível em: <https://foreignpolicy.com/2018/05/18/mauricio-macri-wassupposed-to-be-different/>. Acesso em: 16 nov. 2018.

GASPARI, E. A Ditadura Envergonhada. Rio de Janeiro: Intrínseca, 2002.

GASPARI, E. A Ditadura Escancarada. Rio de Janeiro: Intrínseca, 2002.

HEDGES, J. Argentina: A Modern History. New York: I. B. Tauris, 2015.

JOÃO XXIII, PP. Humanae Salutis. Vaticano: [s.n.], 1961.

KLEIN, N. A doutrina do choque: a ascensão do capitalismo do desastre. Rio de Janeiro: Nova Fronteira, 2007.

LIBANIO, J. B. Igreja Contemporânea, encontro com a modernidade. São Paulo: Edições Loyola, 2000.

LÓPEZ, M. H. Stroessner e "Eu": a cumplicidade social com a ditadura (19541989). In: ROLlEMBERG, D.; QUADRAT, S. V. A Construção Social dos Regimes Autoritários: legitimidade, consenso e consentimento no século XX. Rio de Janeiro: Civilização Brasileira, 2011. p. 437-469.

PAULO VI, PP. Discurso do Papa Paulo VI na sede da ONU, 04 de outubro de 1965. Disponível em: <https://w2.vatican.va/content/paulvi/pt/speeches/1965/documents/hf_p-vi_spe_19651004_united-nations.html $>$. Acesso em: 01 dez. 2019.

PAULO VI, PP. Inauguración de la II Asamblea General de los Obispos de America Latina. Medellín, 1968. Disponivel em: $<$ http://w2.vatican.va/content/paulvi/es/homilies/1968/documents/hf_p-vi_hom_19680824.html>. Acesso em: 09 nov. 2018.

PEREIRA, S. C. O legado da "Igreja dos pobres". Pesquisas em Teologia, v. 1, n. 1, p. 22-37, jan./jun. 2018. Disponível em: <http://periodicos.pucrio.br/index.php/pesquisasemteologia/article/view/682/499>. Acesso em: 16 mar. 2020. DOI: http://dx.doi.org/10.46859/PUCRio.Acad.PqTeo.25959409.2018v1n1p22

PIO XII, PP. Mediator Dei. Vaticano: [s.n.], 1947.

PORTANTIERO, J. C. Economía y política en la crisis argentina: 1958-1973. Revista Mexicana de Sociologia, v. 39, p. 531-565, jun. 1977. 
PRADO, L. C. D.; EARP, F. S. O “milagre” brasileiro: crescimento acelerado, integração nacional e concentração de renda. In: FERREIRA, J.; DELGADO, L. D. A. N. O Brasil Republicano: o tempo da ditadura. Rio de Janeiro: Civilização Brasileira, 2007. p. 207-242.

ROHTER, L. Brazil on the rise, the story of a country transformed. [S.1.]: Griffin, 2012.

SCATENA, S. A conferência de Medellín: contexto, preparação, realização, conclusões e recepção. In: BRIGHENTI, A.; PASSOS, J. D. Compêndio das Conferências dos bispos da América Latina e Caribe. São Paulo: Paulus / Paulinas, 2018. p. 72-73.

SCHWARCZ, L. M.; STARLING, H. M. Brasil: uma biografia. São Paulo: Companhia das Letras, 2015.

SOUZA, N. Ação Católica, militância leiga no Brasil: méritos e limites. Revista de Cultura Teológica, v. 1, n. 55, p. 39-59, abr./jun. 2006. DOI: https://doi.org/10.19176/rct.v0i55.15033

VERA, M. G. "Data feliz" no Paraguai. Festejos de 3 de novembro, aniversário de Alfredo Stroessner. In: ROLLEMBERG, D.; QUADRAT, S. V. A construção social dos regimes autoritários: legitimidade, consenso e consentimento no século XX. Rio de Janeiro: Civilização Brasileira, 2011. p. 393-435.

WEBER, M. Sociologia. São Paulo: Ática, 1982.

Pedro Luiz Amorim Pereira

Mestrando em Teologia pela Pontifícia Universidade Católica de São Paulo

São Paulo / SP - Brasil

E-mail: pedrozero@gmail.com

Recebido em: 30/09/19

Aprovado em: 16/03/20 